Article

\title{
Rhizopus oligosporus and Lactobacillus plantarum Co-Fermentation as a Tool for Increasing the Antioxidant Potential of Grass Pea and Flaxseed Oil-Cake Tempe
}

\section{Bożena Stodolak*, Anna Starzyńska-Janiszewska, Magdalena Mika and Agnieszka Wikiera}

Department of Biotechnology and General Technology of Food, Faculty of Food Technology, University of Agriculture in Krakow, 30-149 Krakow, Poland; anna.starzynska@urk.edu.pl (A.S.-J.); magdalena.mika@urk.edu.pl (M.M.); agnieszka.wikiera@urk.edu.pl (A.W.)

* Correspondence: bozena.stodolak@urk.edu.pl

Academic Editor: Maria Atanassova

Received: 21 September 2020; Accepted: 14 October 2020; Published: 16 October 2020

\begin{abstract}
Tempe-type fermentation originating from Indonesia can enhance the antioxidant activity of plant material. However, this biological potential depends on substrates and applied microorganisms. This study aimed to determine whether co-fermentation with Rhizopus oligosporus and Lactobacillus plantarum improved antioxidant activity of tempe obtained from grass pea seeds with flaxseed oil-cake addition (up to $30 \%$ ). For this purpose, substances reacting with Folin-Ciocalteu reagent and free radicals scavenging potential were measured in water-soluble fractions and dialysates from simulated in vitro digestion. Additionally, the water-soluble phenolic profile was estimated. The higher level of water-extractable compounds with antioxidant activity was determined in co-fermentation products than in fungal fermentation products. Moreover, the fermentation process with the use of L. plantarum contributed to a greater accumulation of some phenolic acids (gallic acid, protocatechuic acid) in tempe without having a negative effect on the levels of other phenolic compounds determined in fungal fermented tempe. During in vitro digestion simulating the human digestive tract, more antioxidant compounds were released from products obtained after co-fermentation than fungal fermentation. An addition of $20 \%$ flaxseed oil-cake and the application of bacterial-fungal co-fermentation, can be considered as an alternative tool to enhance the antioxidant parameters of grass pea tempe.
\end{abstract}

Keywords: antiradical activity; total phenols; water-soluble fraction; co-fermentation; flaxseed oil-cake; grass pea tempe

\section{Introduction}

Tempe is a food product of Indonesian origin obtained from legumes (mainly soy), cereals or agricultural waste via solid state fermentation. The indispensable microorganism in tempe-type fermentation is Rhizopus sp., usually R. oligosporus [1]. Tempe production can be regarded as an alternative way of processing legume seeds to obtain convenient foods of diversified nutritional, organoleptic and bioactive properties. An interesting example is grass pea (Lathyrus sativus L.) seeds, which contain valuable proteins and a relatively high level of mineral compounds. Grass pea seeds from European countries are considered a good source of phenols in a vegetarian diet, with dominant $p$-coumaric acid derivatives in the phenolic profile [2]. Moreover, fermentation of grass pea seeds with Rhizopus strains was proven to significantly enhance the total phenol level and antioxidant potential of the substrate [3].

The inclusion of flaxseed oil-cake as a co-substrate in grass pea-based tempe creates additional opportunities to enrich the nutritional and bioactive potential of the product. Due to its high nutritional 
value, flaxseed oil-cake obtained after cold press oil extraction can be used as a food ingredient. The introduction of flaxseed or flaxseed processing by-products to various plant-derived matrices usually enriches the material in phenols and enhances its antioxidant potential, as proven in the case of bread [4] and grass pea tempe [5]. Flaxseed is the richest source of lignans, mainly secoisolariciresinol (SECO) and its glucoside SDG (secoisolariciresinol diglucoside) of proved antioxidant activities [6].

Though the tempe-type processing can be considered a relatively simple fermentation technique, the selection of the microorganism and the optimal conditions for its growth are indispensable for obtaining products of favourable properties. When alternative substrates such as agricultural by-products are included, an advantageous option can be to introduce into the inoculum a microorganism whose activity would support the growth and activity of the Rhizopus strain. Lactic acid bacteria (LAB) derived from seeds or microbial starters can take part in the tempe fermentation process and contribute to the suppression of spoilage microflora, and thus prolong the shelf life of tempe [1]. Moreover, simultaneous growth of R. oligosporus and L. plantarum on common beans was proven to result in tempe products of improved nutritional composition as well as diversified antioxidant activity [7]. Lactic acid bacteria (LAB) are commonly applied in food fermentations, and Lactobacillus plantarum is most frequently used for plant materials [8].

The purpose of the experiment was to determine whether the presence of LAB during the tempe-type fermentation of grass pea seeds with flaxseed oil-cake addition allows obtaining a product with more advantageous antioxidant parameters than the process carried out only with the use of mould. Different grass pea and flaxseed oil-cake mixtures were tested in order to obtain the combination that ensures obtaining a product with the highest bioactive potential.

\section{Results and Discussion}

\subsection{Antioxidant Activity}

\subsubsection{Substances Reacting with Folin-Ciocalteu Reagent}

The level of compounds reacting with Folin-Ciocalteu reagent (FCRS) depended on the substrate kind-the addition of 10\% (FOC10) and 20\% (FOC20) flaxseed oil-cake to grass pea seeds resulted in an increase in FCRS by $67 \%$ and $87 \%$, respectively, whereas the highest dose (30\%) of oil-cake (FOC30) did not further enrich the tempe in the said compounds (Table 1). The fermentation method also had a significant impact on the FCRS levels. In the fungal fermentation products, around $115 \%$ more FCRS was determined than in the respective substrates. The application of fungal-bacterial inoculum resulted in a small, though significant (by $5 \%$ ), increase in FCRS, as compared to the material fermented solely with mould. The highest levels of FCRS were measured after the bioprocessing of FOC20 and exceeded the values reported for fermented and co-fermented FOC 0 by $78 \%$ and $92 \%$, respectively. Substances that react with Folin-Ciocalteu reagent are mainly phenolic compounds. Therefore, the increase in FCRS observed after fermentation was most likely the result of the release of phenols from their glycosides or the enhanced solubility of phenols due to the action of microbial enzymes. The release of phenols has often been correlated with increased activity of $\beta$-glucosidase, but also $\alpha$-amylase and xylanase $[9,10]$. The influence of LAB on the accumulation of soluble phenols could be of two types: (i) indirect, because bacteria could support the development of mycelium, therefore contributing to the greater activity of fungal $\beta$-glucosidases, and (ii) direct, as L. plantarum could also synthesize the aforementioned enzymes [11,12]. 
Table 1. Antioxidant activity of substrates and fermented products.

\begin{tabular}{|c|c|c|c|c|c|}
\hline & & $\begin{array}{c}\text { FCRS } \\
\text { (mg/g DM) }\end{array}$ & $\begin{array}{l}\text { OH-SA } \\
\text { (ED50) }\end{array}$ & $\begin{array}{c}\text { ABTS }^{+}-\text {SA } \\
\text { (mg Trolox/g DM) }\end{array}$ & $\begin{array}{c}\text { ABTS }^{++}-\mathrm{QA} \\
\text { (mg Trolox/g DM) }\end{array}$ \\
\hline \multicolumn{6}{|c|}{$\begin{array}{l}\text { Treatment Kind } \times \\
\text { Substrate Kind }\end{array}$} \\
\hline \multirow{4}{*}{ 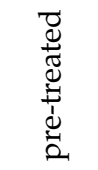 } & FOC0 & $1.44 \pm 0.01 \mathrm{a}$ & $14.10 \pm 0.27 \mathrm{~h}$ & $2.14 \pm 0.03 a$ & $9.27 \pm 0.18 a$ \\
\hline & FOC10 & $2.23 \pm 0.01 b$ & $9.52 \pm 0.11 \mathrm{~g}$ & $3.17 \pm 0.05 b$ & $9.66 \pm 0.34 \mathrm{ab}$ \\
\hline & FOC20 & $2.75 \pm 0.00 c$ & $5.33 \pm 0.08 \mathrm{e}$ & $4.19 \pm 0.03 c$ & $9.52 \pm 0.18 \mathrm{a}$ \\
\hline & FOC30 & $3.28 \pm 0.01 \mathrm{~d}$ & $6.84 \pm 0.06 \mathrm{f}$ & $4.11 \pm 0.02 \mathrm{c}$ & $9.80 \pm 0.34 \mathrm{ab}$ \\
\hline \multirow{4}{*}{ 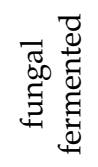 } & FOC0 & $3.40 \pm 0.02 \mathrm{de}$ & $4.61 \pm 0.06 \mathrm{~d}$ & $5.72 \pm 0.05 \mathrm{~d}$ & $11.14 \pm 0.37 \mathrm{bc}$ \\
\hline & FOC10 & $5.68 \pm 0.05 \mathrm{f}$ & $3.77 \pm 0.03 b c$ & $8.44 \pm 0.04 \mathrm{f}$ & $12.33 \pm 0.22$ cde \\
\hline & FOC20 & $6.07 \pm 0.06 \mathrm{~g}$ & $3.50 \pm 0.14 b$ & $8.56 \pm 0.01 \mathrm{~g}$ & $12.65 \pm 0.21 \mathrm{de}$ \\
\hline & FOC30 & $5.64 \pm 0.06 \mathrm{f}$ & $2.79 \pm 0.02 \mathrm{a}$ & $7.53 \pm 0.05 \mathrm{e}$ & $11.95 \pm 0.08$ cde \\
\hline \multirow{4}{*}{ ১ } & FOC0 & $3.51 \pm 0.06 \mathrm{e}$ & $4.22 \pm 0.10 \mathrm{~cd}$ & $5.74 \pm 0.06 \mathrm{~d}$ & $11.65 \pm 0.30 \mathrm{~cd}$ \\
\hline & FOC10 & $6.01 \pm 0.02 \mathrm{~g}$ & $3.71 \pm 0.02 b c$ & $8.49 \pm 0.05 \mathrm{f}$ & $12.97 \pm 0.22 \mathrm{de}$ \\
\hline & FOC20 & $6.75 \pm 0.06 \mathrm{~h}$ & $2.97 \pm 0.02 \mathrm{a}$ & $8.73 \pm 0.05 \mathrm{~g}$ & $13.35 \pm 0.17 \mathrm{e}$ \\
\hline & FOC30 & $5.59 \pm 0.05 \mathrm{f}$ & $2.77 \pm 0.02 \mathrm{a}$ & $7.34 \pm 0.06 \mathrm{e}$ & $11.94 \pm 0.63$ cde \\
\hline \multicolumn{6}{|c|}{ Treatment Kind } \\
\hline \multirow{3}{*}{\multicolumn{2}{|c|}{$\begin{array}{c}\text { pre-treated } \\
\text { fungal fermented } \\
\text { co-fermented }\end{array}$}} & $2.41 \pm 0.16 \mathrm{~A}$ & $8.95 \pm 0.70 \mathrm{C}$ & $3.39 \pm 0.16 \mathrm{~A}$ & $9.56 \pm 0.13 \mathrm{~A}$ \\
\hline & & $5.19 \pm 0.26 \mathrm{~B}$ & $3.66 \pm 0.13 \mathrm{~B}$ & $7.56 \pm 0.24 \mathrm{~B}$ & $12.01 \pm 0.16 \mathrm{~B}$ \\
\hline & & $5.47 \pm 0.30 \mathrm{C}$ & $3.42 \pm 0.11 \mathrm{~A}$ & $7.57 \pm 0.25 \mathrm{~B}$ & $12.48 \pm 0.24 \mathrm{~B}$ \\
\hline \multicolumn{6}{|c|}{ Substrate Kind } \\
\hline \multicolumn{2}{|c|}{ FOC0 } & $2.77 \pm 0.29 \mathrm{~A}$ & $7.65 \pm 1.10 \mathrm{C}$ & $4.54 \pm 0.40 \mathrm{~A}$ & $10.68 \pm 0.32 \mathrm{~A}$ \\
\hline \multicolumn{2}{|c|}{ FOC10 } & $4.64 \pm 0.51 \mathrm{~B}$ & $5.68 \pm 0.67 \mathrm{~B}$ & $6.69 \pm 0.61 C$ & $11.66 \pm 0.40 \mathrm{~B}$ \\
\hline \multicolumn{2}{|c|}{ FOC20 } & $5.20 \pm 0.53 \mathrm{D}$ & $3.92 \pm 0.24 \mathrm{~A}$ & $7.15 \pm 0.50 \mathrm{D}$ & $11.84 \pm 0.45 \mathrm{~B}$ \\
\hline \multicolumn{2}{|c|}{ FOC30 } & $4.83 \pm 0.32 \mathrm{C}$ & $4.14 \pm 0.45 \mathrm{~A}$ & $6.33 \pm 0.37 \mathrm{~B}$ & $11.24 \pm 0.34 \mathrm{AB}$ \\
\hline
\end{tabular}

Two-way analysis of variance and Tuckey post-hoc test were applied (treatment kind-factor 1; substrate kind-factor 2; substrate kind $\times$ treatment kind-interaction between factors). Data are shown as the mean $\pm \mathrm{SEM}$. Mean values within a column followed by different letters differ significantly $(p \leq 0.05)$. FCRS-Folin-Ciocalteu reacting substances; $\mathrm{ABTS}^{+}{ }_{-}^{-S A}-\mathrm{ABTS}^{+}{ }^{+}$-scavenging assay; $\mathrm{OH}^{-}-\mathrm{SA}-\mathrm{OH}^{-}$-scavenging assay; $\mathrm{ABTS}^{+}-\mathrm{QA}-\mathrm{ABTS}^{+}{ }^{-}$quencher assay; ED50-effective dose; substrates: FOC0 — grass pea seeds, FOC10-FOC30-grass pea seeds with a 10-30\% $(w / w)$ flaxseed oil-cake addition.

\subsection{2. $\mathrm{ABTS}^{+\bullet}$ Scavenging Activity}

The ability to neutralize ABTS $^{+\bullet}$ was measured by means of two methods. The quencher method (QA) allows estimating the total antiradical potential that results from the presence of both soluble and insoluble compounds in the material. The method applied to extracts (SA) captures the activity of the fraction soluble in a specific phase, here-in a neutral $\mathrm{pH}$ buffer. Fermentation resulted in an increased total $\mathrm{ABTS}^{+\bullet}$ scavenging activity by $28 \%$ (Table 1 ). The activity of $\mathrm{ABTS}^{+\bullet}$ neutralization by the soluble fraction was $123 \%$ higher in both fungal and fungal-bacterial fermentation products, as compared to the respective substrates. The magnitude of this change suggests that the metabolic activity of mycelium improved the solubility of antiradical components in the material. As previously shown, in legume seeds the $\mathrm{ABTS}^{+\bullet}$ scavenging activity resulting from the presence of insoluble-bound phenols exceeds the antiradical potential of free phenolic compounds [13]. As observed for fermentation substrates, the $\mathrm{ABTS}^{+\bullet}$-scavenging assay (SA) accounted for $23 \%$ (FOC0) to $44 \%$ (FOC20) of ABTS $^{+\bullet}$ -quencher assay (QA), whereas for tempe-as much as 51\% (FOC0) to 67-68\% (FOC10 and FOC20) (Figure 1). The ABTS ${ }^{+\bullet}$-SA was significantly influenced by the substrate kind (Table 1). Products obtained from FOC20 were characterised by the highest antiradical activity ( $8.6 \mathrm{mg}$ Trolox/g DM), $50 \%$ higher than that of tempe made solely from grass pea seeds. Statistical analysis did not prove that bacterial fermentation increased the antiradical potential of the products, which confirms earlier findings according to which fermentation of legumes with L. plantarum does not necessarily result in 
the greater antiradical activity of the soluble fraction. The effect is largely dependent on the legume species [11].

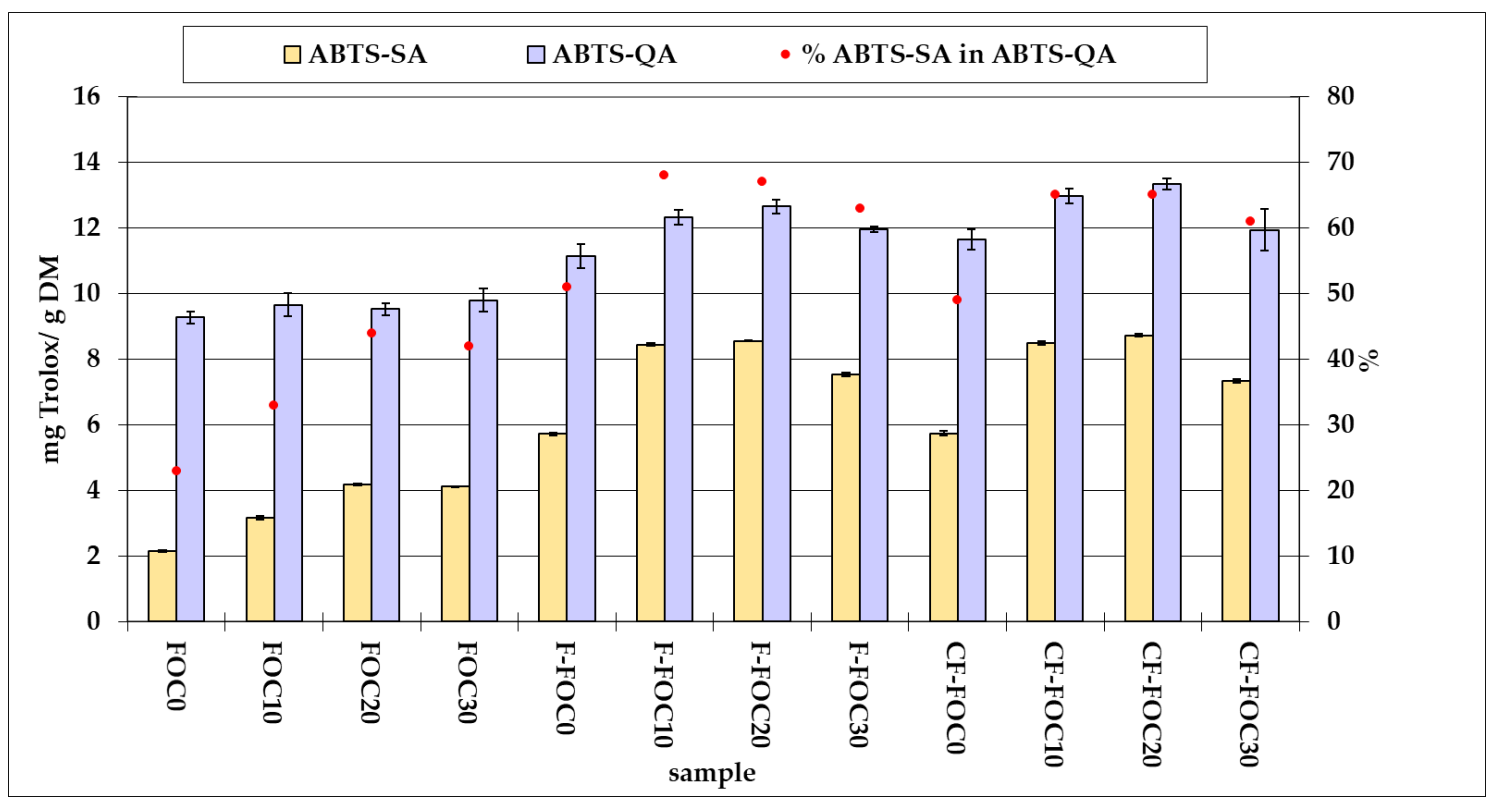

Figure 1. Effect of substrate kind and type of fermentation on ABTS ${ }^{+}$scavenging activity. Data are shown as the mean \pm SEM; FOC0 - grass pea seeds, FOC10-FOC30-grass pea seeds with a 10-30\% $(w / w)$ flaxseed oil-cake addition; F-fermented; CF-co-fermented; ABTS-SA-ABTS ${ }^{+}$-scavenging assay; ABTS-QA-ABTS ${ }^{+}$-quencher assay.

\subsubsection{Hydroxyl Radical Scavenging Activity}

The method applied in the experiment allows measuring the overall potential to both prevent the generation of ${ }^{\bullet} \mathrm{OH}$ in the Fenton reaction and its neutralization [14]. ${ }^{\bullet} \mathrm{OH}-\mathrm{SA}$ depended on the substrate kind, being higher with the increase in oil-cake content up to $20 \%$, and also on the fermentation method (Table 1). The mean effective dose (ED50) measured for fungal and fungal-bacterial fermentation products accounted for $41 \%$ and $38 \%$, respectively, of ED50 of the substrates prepared for inoculation. Tempe obtained from FOC20 and FOC30 by means of co-fermentation were characterised by the highest ${ }^{\bullet} \mathrm{OH}-\mathrm{SA}$ (ED50 accounted for $65 \%$ of the values measured for the FOC0 tempe).

\subsection{The Profile of Phenolic Compounds}

It is acknowledged that a solvent used for phenolic extraction strongly influences the amount and composition of the extracted compounds [15]. In this study, buffer with a neutral $\mathrm{pH}$ and low ionic strength was applied because all the antioxidant potential assessments were performed for aqueous extracts. Moreover, water-soluble compounds are most easily accessible during digestion.

The most common hydroxybenzoic acids were detected in the FOC0 substrate. The level of p-hydroxybenzoic acid and protocatechuic acid was 3 and $0.045 \mu \mathrm{g} / \mathrm{g} \mathrm{DM}$, respectively. Gallic acid was not found. The content of hydroxycinnamic acids ranged from about 3 to $0.3 \mu \mathrm{g} / \mathrm{g} \mathrm{DM}$ for chlorogenic acid, and ferulic and sinapic acid, respectively (Table 2). The amounts determined in the extracts were considerably lower than those reported by Fratianni et al. [16]. However, it should be mentioned that grass pea seeds were subjected to soaking, dehulling and cooking prior to inoculation with microorganisms. Phenolic compounds in legume seeds are usually located in the hulls [17]. Water-soluble compounds may also have been washed from the seeds during soaking and boiling [17]. 
Table 2. Profile of phenolic compounds in substrates and fermented products.

\begin{tabular}{|c|c|c|c|c|}
\hline & & Pre-Treated & Fungal Fermented & Co-Fermented \\
\hline \multicolumn{5}{|c|}{ Gallic Acid ( $\mu \mathrm{g} / \mathrm{g}$ DM) } \\
\hline \multirow{4}{*}{ 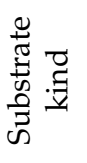 } & FOC0 & $0.000 \pm 0.000 \mathrm{aA}$ & $1.444 \pm 0.485 \mathrm{bA}$ & $3.691 \pm 0.065 \mathrm{cA}$ \\
\hline & FOC10 & $1.100 \pm 0.023 \mathrm{aA}$ & $4.320 \pm 0.588 \mathrm{bA}$ & $3.939 \pm 0.036 \mathrm{bA}$ \\
\hline & FOC20 & $5.606 \pm 0.395 \mathrm{aB}$ & $4.291 \pm 0.794 \mathrm{aA}$ & $5.337 \pm 0.240 \mathrm{aB}$ \\
\hline & FOC30 & $9.362 \pm 0.210 \mathrm{bC}$ & $3.248 \pm 0.008 \mathrm{aA}$ & $3.368 \pm 0.492 \mathrm{aA}$ \\
\hline \multicolumn{5}{|c|}{ Protocatechuic Acid ( $\mu$ g/g DM) } \\
\hline \multirow{4}{*}{ 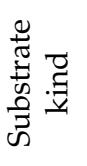 } & FOC0 & $0.045 \pm 0.014 \mathrm{aA}$ & $0.079 \pm 0.010 \mathrm{aA}$ & $4.173 \pm 0.104 \mathrm{bB}$ \\
\hline & FOC10 & $0.050 \pm 0.006 \mathrm{aA}$ & $3.058 \pm 0.098 \mathrm{bB}$ & $5.799 \pm 0.404 \mathrm{cC}$ \\
\hline & FOC20 & $0.050 \pm 0.015 \mathrm{aA}$ & $4.118 \pm 0.048 \mathrm{bC}$ & $4.320 \pm 0.122 \mathrm{bB}$ \\
\hline & FOC30 & $0.059 \pm 0.003 \mathrm{aA}$ & $2.640 \pm 0.204 \mathrm{bB}$ & $2.657 \pm 0.246 \mathrm{bA}$ \\
\hline \multicolumn{5}{|c|}{$p$-Hydroxybenzoic Acid ( $\mu \mathrm{g} / \mathrm{g}$ DM) } \\
\hline \multirow{4}{*}{ 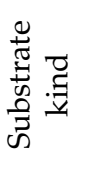 } & FOC0 & $2.972 \pm 0.639 \mathrm{aA}$ & $30.984 \pm 1.218 \mathrm{cA}$ & $27.124 \pm 0.315 \mathrm{bA}$ \\
\hline & FOC10 & $2.933 \pm 0.567 \mathrm{aA}$ & $31.813 \pm 1.933 \mathrm{bA}$ & $31.892 \pm 0.631 \mathrm{bB}$ \\
\hline & FOC20 & $14.651 \pm 1.714 \mathrm{aB}$ & $30.278 \pm 1.915 \mathrm{bA}$ & $26.073 \pm 1.563 \mathrm{bA}$ \\
\hline & FOC30 & $18.731 \pm 0.035 \mathrm{aC}$ & $40.220 \pm 0.991 \mathrm{bB}$ & $41.189 \pm 1.337 \mathrm{bC}$ \\
\hline \multicolumn{5}{|c|}{ Vanillic Acid ( $\mu \mathrm{g} / \mathrm{g} D \mathrm{DM})$} \\
\hline \multirow{4}{*}{ 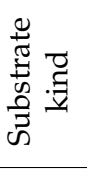 } & FOC0 & $0.161 \pm 0.053 \mathrm{aA}$ & $1.454 \pm 0.239 \mathrm{bA}$ & $1.169 \pm 0.064 \mathrm{bA}$ \\
\hline & FOC10 & $0.767 \pm 0.125 \mathrm{aAB}$ & $3.437 \pm 0.674 \mathrm{aAB}$ & $3.924 \pm 1.316 \mathrm{aA}$ \\
\hline & FOC20 & $1.914 \pm 0.041 \mathrm{aBC}$ & $1.968 \pm 0.165 \mathrm{aAB}$ & $2.452 \pm 0.630 \mathrm{aA}$ \\
\hline & FOC30 & $2.813 \pm 0.471 \mathrm{aC}$ & $3.802 \pm 0.320 \mathrm{aB}$ & $4.780 \pm 0.042 \mathrm{aA}$ \\
\hline \multicolumn{5}{|c|}{ Syringic Acid ( $\mu \mathrm{g} / \mathrm{g} D M)$} \\
\hline \multirow{4}{*}{ 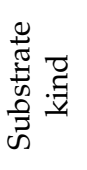 } & FOC0 & $1.488 \pm 0.045$ & $1.336 \pm 0.023$ & $1.570 \pm 0.132$ \\
\hline & FOC10 & $1.378 \pm 0.156$ & $1.541 \pm 0.040$ & $1.163 \pm 0.249$ \\
\hline & FOC20 & $1.045 \pm 0.092$ & $0.976 \pm 0.188$ & $0.821 \pm 0.316$ \\
\hline & FOC30 & $1.004 \pm 0.032$ & $0.814 \pm 0.246$ & $2.244 \pm 0.648$ \\
\hline \multicolumn{5}{|c|}{ Chlorogenic Acid ( $\mu \mathrm{g} / \mathrm{g} D \mathrm{DM})$} \\
\hline \multirow{4}{*}{ 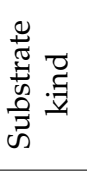 } & FOC0 & $2.886 \pm 0.081 \mathrm{bA}$ & $1.054 \pm 0.278 \mathrm{aA}$ & $0.726 \pm 0.081 \mathrm{aA}$ \\
\hline & FOC10 & $3.501 \pm 0.716 \mathrm{bA}$ & $0.882 \pm 0.031 \mathrm{aA}$ & $0.602 \pm 0.048 \mathrm{aA}$ \\
\hline & FOC20 & $2.446 \pm 0.063 \mathrm{bA}$ & $0.492 \pm 0.016 \mathrm{aA}$ & $0.341 \pm 0.077 \mathrm{aA}$ \\
\hline & FOC30 & $2.203 \pm 0.152 \mathrm{bA}$ & $0.875 \pm 0.096 \mathrm{aA}$ & $0.594 \pm 0.069 \mathrm{aA}$ \\
\hline \multicolumn{5}{|c|}{ Caffeic Acid ( $\mu \mathrm{g} / \mathrm{g}$ DM) } \\
\hline \multirow{4}{*}{ 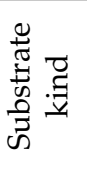 } & FOC0 & $0.426 \pm 0.031 \mathrm{aA}$ & $3.176 \pm 0.056 \mathrm{cA}$ & $2.716 \pm 0.001 \mathrm{bA}$ \\
\hline & FOC10 & $1.191 \pm 0.040 \mathrm{aB}$ & $3.184 \pm 0.102 \mathrm{bA}$ & $2.904 \pm 0.348 \mathrm{bA}$ \\
\hline & FOC20 & $2.427 \pm 0.098 \mathrm{aC}$ & $3.842 \pm 0.105 \mathrm{bB}$ & $3.957 \pm 0.191 \mathrm{bB}$ \\
\hline & FOC30 & $3.895 \pm 0.267 \mathrm{aD}$ & $4.786 \pm 0.179 \mathrm{abC}$ & $5.702 \pm 0.197 \mathrm{bC}$ \\
\hline \multicolumn{5}{|c|}{$p$-Coumaric Acid ( $\mu \mathrm{g} / \mathrm{g} \mathrm{DM})$} \\
\hline \multirow{4}{*}{ 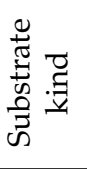 } & FOC0 & $0.541 \pm 0.018 \mathrm{aA}$ & $0.680 \pm 0.021 \mathrm{bA}$ & $0.798 \pm 0.032 \mathrm{cA}$ \\
\hline & FOC10 & $1.908 \pm 0.038 \mathrm{bB}$ & $1.668 \pm 0.041 \mathrm{bB}$ & $1.069 \pm 0.169 \mathrm{aA}$ \\
\hline & FOC20 & $2.617 \pm 0.057 \mathrm{bC}$ & $2.184 \pm 0.049 \mathrm{aC}$ & $2.192 \pm 0.090 \mathrm{aB}$ \\
\hline & FOC30 & $3.639 \pm 0.157 \mathrm{bD}$ & $2.565 \pm 0.200 \mathrm{aD}$ & $3.360 \pm 0.055 \mathrm{bC}$ \\
\hline \multicolumn{5}{|c|}{ Ferulic \& Sinapic Acid ( $\mu$ g/g DM) } \\
\hline \multirow{4}{*}{ 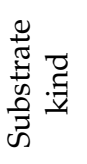 } & FOC0 & $0.338 \pm 0.044 \mathrm{aA}$ & $0.239 \pm 0.009 \mathrm{aA}$ & $0.169 \pm 0.036 \mathrm{aA}$ \\
\hline & FOC10 & $1.977 \pm 0.275 \mathrm{bB}$ & $0.993 \pm 0.004 \mathrm{aB}$ & $0.688 \pm 0.147 \mathrm{aB}$ \\
\hline & FOC20 & $2.750 \pm 0.072 \mathrm{bC}$ & $1.933 \pm 0.102 \mathrm{aC}$ & $1.899 \pm 0.020 \mathrm{aC}$ \\
\hline & FOC30 & $3.857 \pm 0.168 \mathrm{cD}$ & $1.959 \pm 0.166 \mathrm{aC}$ & $2.849 \pm 0.098 \mathrm{bD}$ \\
\hline \multicolumn{5}{|c|}{ Secoisolariciresinol (SECO) ( $\mu \mathrm{g} / \mathrm{g}$ DM) } \\
\hline \multirow{4}{*}{ 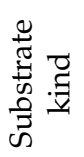 } & FOC0 & $0.00 \mathrm{~A}$ & $0.00 \mathrm{~A}$ & $0.00 \mathrm{~A}$ \\
\hline & FOC10 & $0.609 \pm 0.042 \mathrm{aAB}$ & $0.440 \pm 0.015 \mathrm{aAB}$ & $0.386 \pm 0.121 \mathrm{aA}$ \\
\hline & FOC20 & $0.748 \pm 0.036 \mathrm{aAB}$ & $0.870 \pm 0.009 \mathrm{bBC}$ & $0.669 \pm 0.006 \mathrm{aA}$ \\
\hline & FOC30 & $1.305 \pm 0.399 \mathrm{aB}$ & $2.230 \pm 0.348 \mathrm{aC}$ & $1.322 \pm 0.479 \mathrm{aA}$ \\
\hline
\end{tabular}


Table 2. Cont.

\begin{tabular}{|c|c|c|c|c|}
\hline & & Pre-Treated & Fungal Fermented & Co-Fermented \\
\hline \multicolumn{5}{|c|}{ Secoisolariciresinol Diglucoside (SDG) $(\mu \mathrm{g} / \mathrm{g} \mathrm{DM})$} \\
\hline \multirow{4}{*}{ 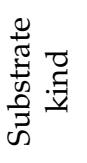 } & FOC0 & $0.00 \mathrm{~A}$ & $0.00 \mathrm{~A}$ & $0.00 \mathrm{~A}$ \\
\hline & FOC10 & $2.569 \pm 0.053 \mathrm{aB}$ & $2.679 \pm 0.373 \mathrm{aB}$ & $2.645 \pm 0.282 \mathrm{aB}$ \\
\hline & FOC20 & $6.759 \pm 0.226 \mathrm{aC}$ & $6.124 \pm 0.235 \mathrm{aC}$ & $6.345 \pm 0.118 \mathrm{aB}$ \\
\hline & FOC30 & $12.942 \pm 0.013 \mathrm{bD}$ & $8.736 \pm 1.178 \mathrm{aD}$ & $10.417 \pm 0.021 \mathrm{abD}$ \\
\hline \multicolumn{5}{|c|}{ Secoisolariciresinol Diglucoside Oligomers (SDG Oligomers) ( $\mu \mathrm{g} / \mathrm{g}$ DM) } \\
\hline \multirow{4}{*}{ 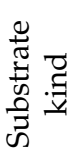 } & FOC0 & $0.00 \mathrm{~A}$ & $0.00 \mathrm{~A}$ & $0.00 \mathrm{~A}$ \\
\hline & FOC10 & $216.108 \pm 14.154 \mathrm{aB}$ & $191.644 \pm 4.805 \mathrm{aB}$ & $249.658 \pm 8.340 \mathrm{aB}$ \\
\hline & FOC20 & $340.146 \pm 39.628 \mathrm{aBC}$ & $687.715 \pm 22.626 \mathrm{bC}$ & $787.046 \pm 7.599 \mathrm{bC}$ \\
\hline & FOC30 & $422.054 \pm 83.111 \mathrm{aC}$ & $310.644 \pm 21.656 \mathrm{aD}$ & $275.049 \pm 25.153 \mathrm{aB}$ \\
\hline \multicolumn{5}{|c|}{ Sum ( $\mu \mathrm{g} / \mathrm{g} D M)$} \\
\hline \multirow{4}{*}{ 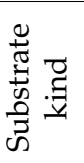 } & FOC0 & $8.919 \pm 0.816 \mathrm{aA}$ & $40.547 \pm 1.598 \mathrm{bA}$ & $42.220 \pm 0.187 \mathrm{bA}$ \\
\hline & FOC10 & $234.458 \pm 14.405 \mathrm{aB}$ & $246.029 \pm 6.972 \mathrm{aB}$ & $305.107 \pm 7.092 \mathrm{bB}$ \\
\hline & FOC20 & $381.978 \pm 40.944 \mathrm{aBC}$ & $745.862 \pm 24.884 \mathrm{bC}$ & $842.627 \pm 8.865 b C$ \\
\hline & FOC30 & $482.879 \pm 83.162 \mathrm{aC}$ & $384.191 \pm 22.043 \mathrm{aD}$ & $355.804 \pm 28.112 \mathrm{aB}$ \\
\hline
\end{tabular}

For each phenolic compound, one-way ANOVA was applied. Data are shown as the mean \pm SEM Mean values within a column followed by different big letters differ significantly $(p \leq 0.05)$. Mean values within a row followed by different small letters differ significantly $(p \leq 0.05)$. Substrates: FOC0 - grass pea seeds, FOC10-FOC30—grass pea seeds with a $10-30 \%(w / w)$ flaxseed oil-cake addition.

The addition of flaxseed oil-cake to grass pea seeds resulted in the appearance of gallic acid and an increase in its amount depending on the oil-cake dose, up to over $9 \mu \mathrm{g} / \mathrm{g} D \mathrm{DM}$. The presence of oil-cake in the material also caused the accumulation of other phenolic acids. In FOC30, an increase from 6-fold (p-hydroxybenzoic acid) to 17-fold (vanillic acid) was observed. Flaxseed oil-cake did not influence the level of protocatechuic, syringic and chlorogenic acids in the material (Table 2). However, oil-cake was the only source of lignan-SECO, and its glycoside-SDG. In the chromatograms of the substrates and the tempe containing oil-cake, a peak with a retention time of $45.815 \mathrm{~min}$ and a spectrum corresponding to or very close to the spectrum of SDG and SECO was visible (Table 3). On this basis, it was identified as SDG oligomers. Lignan oligomers from flaxseed are composed of SDG and herbacetin diglucoside ester-linked by 3-hydroxy-3-methylglutaric acid and $p$-coumaric acid glucoside, as well as ferulic acid glucoside ester-linked to SDG [18]. The content of SDG oligomers in the fermentation substrates ranged from 216 to $422 \mu \mathrm{g} / \mathrm{g} \mathrm{DM}$, depending on the oil-cake share in the material.

Fungal fermentation resulted in a noticeable increase in gallic acid, but only in the case of material containing a maximum of $10 \%$ flaxseed oil-cake. The addition of L. plantarum to the inoculum caused further accumulation of gallic acid only in FOC0. The observed phenomenon could have resulted from the decomposition of hydrolysing tannins. It has been proven that moulds such as Aspergillus sp, Penicillium sp. and Rhizopus oryzae produce tannases [19]. Therefore, it is possible that $R$. oligosporus DSM 1967 applied in the present experiment also has such activity. The role of L. plantarum in the release of gallic acid from hydrolysing tannins has been confirmed in a different study [8].

Fungal fermentation also resulted in an increase in the protocatechuic acid (with the exception of FOC0) and p-hydroxybenzoic acid. Co-fermentation promoted the further accumulation of protocatechuic acid but only in materials that contained up to $10 \%$ flaxseed oil-cake. Tempe products obtained with mixed inoculum were characterised by a 45 to 116 -fold higher level of protocatechuic acid, as compared to the values measured in FOC 30 and FOC10 substrates, respectively. The change in the level of $p$-hydroxybenzoic acid observed after fermentation was by far the most pronounced (10-fold) in the case of FOC0 and FOC10. The level of the said compound was undoubtedly the highest among all phenolic acids determined in aqueous extracts, at an average of $32 \mu \mathrm{g} / \mathrm{g}$ DM in tempe. Protocatechuic and $p$-hydroxybenzoic acids can be a metabolite of both fungi and bacteria [20,21]. It has been proven that these compounds show antioxidant activity [22] and additionally protocatechuic 
acid is capable of up-regulation of antioxidant enzymes (e.g., glutathione peroxidase and glutathione reductase) expression [23]. With regard to hydroxycinnamic acids, fungal fermentation resulted in a significant decrease in the chlorogenic acid content, from $70 \%$ (FOC0) to more than $80 \%$ (FOC20), as well as a decrease in the content of ferulic and sinapic acid in products containing oil-cake, by $30 \%$ (FOC20) to 50\% (FOC10 and FOC30). On the other hand, in tempe obtained after fermentation with $R$. oligosporus alone, more caffeic acid was determined, by about $60 \%$ (FOC20) to as much as $645 \%$ (FOC0). The decrease in chlorogenic acid observed after tempe fermentation indicates that $R$. oligosporus DSM 1964 showed esterase activity capable of hydrolysing this phenol. Slightly lower levels of chlorogenic acid (no statistically significant differences) measured in co-fermented material, as compared to fungal fermented one, might be caused by bacterial activity. Sánchez-Maldonado et al. [24] showed that L. plantarum metabolizes chlorogenic acid to caffeic acid to a small extent. When grass pea seeds alone were used as the fermentation substrate, fungal fermentation and co-fermentation resulted in an increase in the level of p-coumaric acid, by $25 \%$ and $47 \%$, respectively.

The fermentation process generally had no effect on SECO and SDG levels in samples containing flaxseed oil-cake (Table 2). Nevertheless, the presence of these compounds in the aforementioned substrates and products could enhance their antioxidant potential, as compared to FOC0. Both SECO and SDG show antioxidant activity [6]. Fungal fermentation resulted in an increase in SDG oligomers only in the case of FOC20. The observed two-fold rise of SDG oligomers can only be explained by an increase in their extractability as a result of the metabolic activity of $R$. oligosporus mycelium that loosened cell structures of flaxseed oil-cake. It should be stressed that after the fermentation of this particular substrate, the highest glucosamine level and dry substance loss (indicators of mycelial growth/activity) were measured (data not shown).

Generally speaking, no clear impact of bacterial activity on the level of water-extractable phenols was observed. The ability of Lactobacillus plantarum to metabolize various phenols with the participation of such enzymes as phenolic acid decarboxylase and acid phenol reductase has been proven. However, the activity of these enzymes is inducible and depends on both the level of available phenols and the bacterial growth conditions [8].

Table 3. Retention time and absorption wavelengths of determined phenolic compounds by HPLC-DAD method.

\begin{tabular}{cccc}
\hline Compound & Retention Time (min) & Absorption Max (nm) & Absorption Min (nm) \\
\hline Gallic acid & 7.9 & $271.8 ; 215.3$ & 240.46 \\
Protocatechuic acid & 14.457 & $294.3 ; 259.5 ; 204.6$ & $282.0 ; 236.0$ \\
Chlorogenic acid & 11.445 & $327.4 ; 247.2 ; 197.9$ & 264.0 \\
p-Hydroxybenzoic acid & 12.6 & $256.1 ; 194.9$ & 236.0 \\
Vanillic acid & 14.51 & $292.1 ; 261.8 ; 201.2$ & $281.95 ; 234.9$ \\
Caffeic acid & 14.93 & $323.2 ; 215.7 ; 193.4$ & 262.8 \\
Syringic acid & 15.07 & $274.1 ; 215.8$ & 241.6 \\
SDG & 19.5 & $280.1 ; 197.9$ & 253.9 \\
Coniferyl alcohol & 20.35 & $264.0 ; 241.6$ & 211.0 \\
p-Coumaric acid & 22.11 & $309.6 ; 223.5 ; 207.9$ & $249.2 ; 217.9$ \\
Sinapic acid & 24.7 & $323.5 ; 199.9$ & 263.9 \\
Ferulic acid & 24.8 & $322.3 ; 212.4 ; 194.5$ & 261.0 \\
SECO & 33.96 & $282.0 ; 197.7$ & 254.9 \\
SDG oligomers & 45.815 & $285.3 ; 195.6$ & 240.5 \\
\hline
\end{tabular}

\subsection{Antioxidant Potential after In Vitro Digestion}

Antioxidant potential was determined in dialysates obtained after in vitro digestion by the FCRS level, $\mathrm{ABTS}^{+\bullet}$-SA and ${ }^{\bullet} \mathrm{OH}-\mathrm{SA}$.

The amount of FCRS released to dialysates depended on the substrate kind (Table 4). The highest level of the said compounds was measured in FOC10 and FOC20. Dialysates obtained from other substrates contained $12 \%$ less FCRS. The bioprocessing method also significantly affected this parameter. 
The digestion of fungal and fungal-bacterial fermented material resulted in the release of $21 \%$ and $35 \%$ more FCRS, respectively, as compared to the substrates. The highest amount of antioxidant compounds was determined in the case of dialysates obtained from co-fermented FOC10 and FOC20, on average, $40 \%$ more than in the case of grass pea tempe. The level of FCRS measured in dialysates after in vitro digestion was highly correlated with $\mathrm{ABTS}^{+\bullet}-\mathrm{SA}\left(\mathrm{R}^{2}=0.92, p=0.000\right)$. Therefore, it is not surprising that very similar changes to those described above were observed for $\mathrm{ABTS}^{+\bullet}$ neutralization activity. The addition of $10 \%$ and $20 \%$ of flaxseed oil-cake increased the ABTS ${ }^{+}-$SA of dialysates by $14 \%$. At the same time, both fungal fermentation and co-fermentation resulted in higher scavenging potential of the samples, by $15 \%$ and $44 \%$, respectively. The best source of compounds capable of $\mathrm{ABTS}^{+\bullet}$ neutralization was tempe obtained after co-fermentation of FOC10 and FOC20.

Table 4. Antioxidant activity of substrates and fermented products after in vitro digestion.

\begin{tabular}{|c|c|c|c|c|}
\hline & & $\begin{array}{c}\text { FCRS } \\
\text { (mg/g DM) }\end{array}$ & $\begin{array}{c}\mathrm{ABTS}^{*+}-\mathrm{SA} \\
\text { (mgTrolox/g DM) }\end{array}$ & $\begin{array}{c}\text { OH-SA } \\
\text { (mgTrolox/g DM) }\end{array}$ \\
\hline \multicolumn{5}{|c|}{$\begin{array}{l}\text { Treatment Kind } x \\
\text { Substrate Kind }\end{array}$} \\
\hline \multirow{4}{*}{ d. } & FOC0 & $9.52 \pm 0.04 b c$ & $22.66 \pm 0.30 \mathrm{abc}$ & $46.02 \pm 3.69 \mathrm{bcd}$ \\
\hline & FOC10 & $8.77 \pm 0.14 \mathrm{ab}$ & $22.02 \pm 0.35 \mathrm{ab}$ & $34.23 \pm 1.87 \mathrm{~b}$ \\
\hline & FOC20 & $8.18 \pm 0.23 \mathrm{a}$ & $20.89 \pm 0.60 b$ & $19.04 \pm 1.02 \mathrm{a}$ \\
\hline & FOC30 & $8.30 \pm 0.22 \mathrm{a}$ & $20.85 \pm 0.19 \mathrm{ab}$ & $15.98 \pm 0.84 \mathrm{a}$ \\
\hline \multirow{4}{*}{ 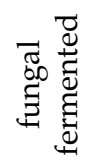 } & FOC0 & $9.96 \pm 0.05 \mathrm{~cd}$ & $24.42 \pm 0.39 \mathrm{~cd}$ & $49.24 \pm 2.00 \mathrm{cde}$ \\
\hline & FOC10 & $10.97 \pm 0.06 \mathrm{e}$ & $26.00 \pm 0.37 \mathrm{~d}$ & $40.50 \pm 3.12 b c$ \\
\hline & FOC20 & $10.91 \pm 0.21 \mathrm{de}$ & $25.80 \pm 0.26 \mathrm{~d}$ & $47.01 \pm 2.00 \mathrm{~cd}$ \\
\hline & FOC30 & $10.10 \pm 0.07$ cde & $23.03 \pm 0.49 \mathrm{bc}$ & $49.74 \pm 0.78$ cde \\
\hline \multirow{4}{*}{ 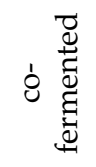 } & FOC0 & $9.56 \pm 0.10 b c$ & $24.28 \pm 0.25 \mathrm{~cd}$ & $61.33 \pm 2.39 \mathrm{e}$ \\
\hline & FOC10 & $13.30 \pm 0.25 \mathrm{f}$ & $34.56 \pm 0.50 \mathrm{f}$ & $59.08 \pm 2.89 \mathrm{de}$ \\
\hline & FOC20 & $13.23 \pm 0.40 \mathrm{f}$ & $34.96 \pm 0.74 \mathrm{f}$ & $97.43 \pm 4.76 \mathrm{f}$ \\
\hline & FOC30 & $10.62 \pm 0.18 \mathrm{de}$ & $30.16 \pm 0.47 \mathrm{e}$ & $59.82 \pm 0.77 \mathrm{e}$ \\
\hline \multicolumn{5}{|c|}{ Treatment Kind } \\
\hline \multirow{3}{*}{\multicolumn{2}{|c|}{$\begin{array}{c}\text { pre-treated } \\
\text { fungal fermented } \\
\text { co-fermented }\end{array}$}} & $8.63 \pm 0.13 \mathrm{~A}$ & $21.55 \pm 0.23 \mathrm{~A}$ & $28.81 \pm 2.71 \mathrm{~A}$ \\
\hline & & $10.45 \pm 0.10 \mathrm{~B}$ & $24.78 \pm 0.28 \mathrm{~B}$ & $46.48 \pm 1.29 \mathrm{~B}$ \\
\hline & & $11.67 \pm 0.31 \mathrm{C}$ & $31.00 \pm 0.80 \mathrm{C}$ & $70.26 \pm 3.90 \mathrm{C}$ \\
\hline \multicolumn{5}{|c|}{ Substrate Kind } \\
\hline \multicolumn{2}{|c|}{ FOC0 } & $9.69 \pm 0.05 \mathrm{~A}$ & $23.88 \pm 0.23 \mathrm{~A}$ & $51.40 \pm 2.05 \mathrm{~B}$ \\
\hline \multicolumn{2}{|c|}{ FOC10 } & $11.01 \pm 0.40 \mathrm{~B}$ & $27.54 \pm 1.11 \mathrm{~B}$ & $43.42 \pm 2.76 \mathrm{~A}$ \\
\hline \multicolumn{2}{|c|}{ FOC20 } & $10.77 \pm 0.49 \mathrm{~B}$ & $27.15 \pm 1.21 \mathrm{~B}$ & $54.49 \pm 8.04 \mathrm{~B}$ \\
\hline \multicolumn{2}{|c|}{ FOC30 } & $9.66 \pm 0.23 \mathrm{~A}$ & $24.77 \pm 0.85 \mathrm{~A}$ & $42.27 \pm 4.33 \mathrm{~A}$ \\
\hline
\end{tabular}

Two-way analysis of variance and Tuckey post-hoc test were applied (treatment kind-factor 1; substrate kind—factor 2; substrate kind $x$ treatment kind-interaction between factors). Data are shown as the mean \pm SEM. Mean values within a column followed by different letters differ significantly $(p \leq 0.05)$. FCRS-Folin-Ciocalteu reacting substances; $\mathrm{ABTS}^{+}{ }^{+} \mathrm{SA}-\mathrm{ABTS}^{+}{ }^{+}$-scavenging assay; $\mathrm{OH}$-SA-OH'scavenging assay; substrates: FOC0 - grass pea seeds, FOC10-FOC30-grass pea seeds with a 10\%-30\% (w/w) flaxseed oil-cake addition.

The contents of FCRS and $\mathrm{ABTS}^{+\bullet}$ scavenging compounds determined in dialysates can be compared to the results obtained for buffer extracts (Section 2.1.1-Section 2.1.2). In vitro digestion alone contributed to a pronounced increase in the antioxidant potential. The amount of FCRS in dialysates was 1.8 to 6.6 -fold higher than the initial FCRS content measured in the materials, whereas the $\mathrm{ABTS}^{+} \bullet$-SA was 3 to 10 -fold higher. Digestive enzymes can promote the release of phenols from plant cells as well as phenols bound with other compounds [25]. The level of FCRS determined in dialysates was also significantly correlated with ${ }^{\bullet} \mathrm{OH}$ scavenging activity $\left(\mathrm{R}^{2}=0.7, p=0.000\right)$. The ${ }^{\bullet} \mathrm{OH}-\mathrm{SA}$ depended on the substrate kind, although it was not directly related to the flaxseed oil-cake level because the highest values were determined for dialysates from FOC0 and FOC20 
(Table 4). The potential of in vitro digestion products to scavenge $\bullet \mathrm{OH}$ depended to a greater extent on the bioprocessing method. Fungal fermentation and co-fermentation caused a $61 \%$ and $144 \%$ increase in the ${ }^{\bullet} \mathrm{OH}-\mathrm{SA}$, respectively, as compared to their substrates. The highest value (approximately $100 \mathrm{mg}$ Trolox/g DM) was determined after the digestion of co-fermented FOC20. This sample was characterised by an ${ }^{\circ} \mathrm{OH}-\mathrm{SA} 60 \%$ higher than other co-fermented materials and about $110 \%$ higher than all fungal fermented products. It is worth mentioning again that tempe from FOC20 was the richest source of water-soluble SDG oligomers. Considering the structure of lignan macromolecule [18], it seems highly probable that they were present in dialysate and could neutralize hydroxyl radicals [6].

\section{Materials and Methods}

\subsection{Fermentation Substrates}

Grass pea (Lathyrus sativus L.) seeds cultivar Krab were obtained from "Spójnia" Hodowla i Nasiennictwo Ogrodnicze (Nochowo, Poland). Cold-pressed flaxseed oil-cake was kindly provided by Przedsiębiorstwo Nasienne CENTRALA NASIENNA Sp. z o.o. (Sanok, Poland).

\subsection{Inoculum}

Tempe strain Rhizopus oligosporus DSM 1962 (German Collection of Microorganism and Cell Cultures) was grown on potato extract agar. Spores were harvested after 12 days with a sterile saline solution $(8 \mathrm{~g} / \mathrm{L})$ supplemented with peptone $(0.01 \mathrm{~g} / \mathrm{L})$ and Tween $80(0.1 \mathrm{~mL} / \mathrm{L})$. Next, the suspension was filtered three times ( $\phi 11 \mu \mathrm{m}$, Nylon Net Filtres, Millipore, Cork, Ireland). The spore density was obtained by the spore-counting method in a Thoma chamber.

Lactobacillus plantarum DSM 20174 was rehydrated from a freeze-dried culture and grown at $30{ }^{\circ} \mathrm{C}$ on de Man, Rogosa and Sharpe (MRS) broth (BioMaxina S.A., Lublin, Poland) for 24 h. The bacterial cells were then centrifuged and suspended in a sterile saline solution. The cell density was measured by the turbidimetric method using McFarland's standards.

\subsection{Preparation of Flaxseed Oil-Cake}

Flaxseed oil-cake was hydrated to $40 \%$ moisture content and simultaneously acidified to $\mathrm{pH}$ 4-5 with an appropriate quantity of $5 \%$ lactic acid, then sterilized $\left(121^{\circ} \mathrm{C}, 20 \mathrm{~min}\right)$ and cooled to room temperature.

\subsection{Preparation of Seeds}

Grass pea seeds were thoroughly cleaned and boiled in tap water for $30 \mathrm{~min}$. Then, they were soaked in tap water for $18 \mathrm{~h}$ at room temperature. Next, the seeds were dehulled by hand and boiled for $15 \mathrm{~min}$ in tap water acidified to $\mathrm{pH} 4.5-5.0$ with lactic acid. After discarding water, the seeds were drained and cooled $\left(<35^{\circ} \mathrm{C}\right)$.

\subsection{Preparation of Fermented Products}

Grass pea seeds alone or with the addition of flaxseed oil-cake were mixed thoroughly with the spore suspension of $R$. oligosporus $\left(2 \cdot 10^{6}\right.$ spores per $100 \mathrm{~g}$ of raw material) or the inoculum containing R. oligosporus $\left(2 \cdot 10^{6}\right.$ spores per $100 \mathrm{~g}$ of raw material) and L. plantarum $\left(2 \cdot 10^{6}\right.$ cells per $100 \mathrm{~g}$ of raw material). The inoculated material was tightly packed in Petri dishes $(\varnothing 11 \mathrm{~cm}$, four Petri dishes for each combination of substrate and fermentation inoculum) and incubated at $30{ }^{\circ} \mathrm{C}$. Fermentation was stopped after $27 \mathrm{~h}$ by steaming the obtained products for $10 \mathrm{~min}$. The tempe samples were lyophilized and stored at $4{ }^{\circ} \mathrm{C}$ for further analysis.

Eight types of grass pea-based-tempe were prepared after fungal and simultaneous fungal-bacterial fermentation of the following substrates: grass pea seeds (FOC0), and grass pea seeds with a 10\%, 20\% and 30\% (w/w) flaxseed oil-cake addition (FOC10, FOC20 and FOC30, respectively). 


\subsection{Preparation of Pre-Treated Substrates}

Grass pea seeds alone (FOC0), as well as grass pea seeds and flaxseed oil-cake mixtures (FOC10-30), subjected to the hydration and sterilization process (as described in Sections 3.3 and 3.4), were lyophilized and kept at $4{ }^{\circ} \mathrm{C}$ for further analysis.

\subsection{Buffer Extracts Preparation}

Lyophilized material was used to prepare extracts at a concentration of $1 \mathrm{~g} / 25 \mathrm{~mL}$ in a sodium-phosphate buffer $(0.02 \mathrm{~mol} / \mathrm{L}, \mathrm{pH} 7.4)$. Extracts were used to measure substances reacting with Folin-Ciocalteu reagent $(\mathrm{FCRS})$ and $\bullet \mathrm{OH}$ and $\mathrm{ABTS}^{+\bullet}$ scavenging activity.

\subsection{Analytical Methods}

Dry matter (DM) was obtained with a moisture analyser (WPS 110S, Radwag, Radom, Poland) at $105^{\circ} \mathrm{C}$.

FCRS were assessed by the method of Swain and Hillis [26]. Briefly, $5 \mathrm{~mL}$ of properly diluted extracts was mixed with $0.25 \mathrm{~mL}$ of $1 \mathrm{~mol} / \mathrm{L}$ Folin-Ciocalteu reagent and $0.5 \mathrm{~mL}$ of saturated $\mathrm{Na}_{2} \mathrm{CO}_{3}$ solution. After $15 \mathrm{~min}$ of incubation, absorbance of the samples was measured at $700 \mathrm{~nm}$ against the reagent blank. The result was expressed as $\mathrm{mg}$ gallic acid/g DM.

The hydroxyl radical $\left({ }^{\bullet} \mathrm{OH}\right)$ scavenging activity $\left({ }^{\bullet} \mathrm{OH}-\mathrm{SA}\right)$ was estimated according to the assay given by Marambe et al. [27]. Briefly, 50-600 $\mu \mathrm{L}$ of extract was mixed with appropriate volume of potassium phosphate buffer $(20 \mathrm{mmol} / \mathrm{L}, \mathrm{pH} 7.4)$ to achieve $1125 \mu \mathrm{L}$ of sample. Next, the following components were sequentially added: $40 \mu \mathrm{L}$ of $0.5 \mathrm{mmol} / \mathrm{L} \mathrm{FeCl}_{3}, 42 \mu \mathrm{L}$ of $2.4 \mathrm{mmol} / \mathrm{L}$ EDTA, $140 \mu \mathrm{L}$ of $0.02 \mathrm{~mol} / \mathrm{L}$ deoxyribose, $10 \mu \mathrm{L}$ of $0.01 \mathrm{~mol} / \mathrm{L}$ ascorbic acid and $142 \mu \mathrm{L}$ of $1 \mathrm{mmol} / \mathrm{L} \mathrm{H}_{2} \mathrm{O}_{2}$. The assay mixture was incubated at $37^{\circ} \mathrm{C}$ for $1 \mathrm{~h}$ and after that $1 \mathrm{~mL}$ of $1 \%(w / v)$ TBA and $1 \mathrm{~mL}$ of $2.8 \%(w / v)$ TCA were added. The sample was incubated at $100{ }^{\circ} \mathrm{C}$ for $20 \mathrm{~min}$, and after cooling to room temperature, the absorbance was measured at $532 \mathrm{~nm}$ against a blank. The blank consisted of all the reagents, to which TBA and TCA were added prior to incubation at $37^{\circ} \mathrm{C}$. The ${ }^{\bullet} \mathrm{OH}-\mathrm{SA}$ was expressed as ED50 (effective dose-defined as $\mathrm{mg}$ of the sample used for the extraction that is required for the inhibition of $50 \%$ free radicals in the reaction conditions) or as $\mathrm{mg}$ Trolox equivalents/g DM.

The ABTS radical scavenging activity (ABTS ${ }^{+\bullet-S A}$ ) was obtained as described by Arnao et al. [28]. To prepare the $\mathrm{ABTS}^{+\bullet}$ solution, $10 \mathrm{mg}$ of ABTS [2,20-azino-bis(3-ethylbenzothiazoline-6-sulfonic acid)] was dissolved in $1.3 \mathrm{~mL}$ of $0.0049 \mathrm{~mol} / \mathrm{L} \mathrm{K} \mathrm{K}_{2} \mathrm{O}_{8}$ and $1.3 \mathrm{~mL}$ of double distilled water, and left for $16 \mathrm{~h}$ at room temperature. Just before analysis, $\mathrm{ABTS}^{+\bullet}$ solution was diluted with phosphate buffer to achieve the absorbance of $0.7 \pm 0.02$ at $734 \mathrm{~nm}$. Next, $2 \mathrm{~mL}$ of ABTS ${ }^{+\bullet}$ solution was mixed with $200 \mu \mathrm{L}$ extract and incubated at room temperature in the dark. After $7 \mathrm{~min}$, the absorbance was measured at $734 \mathrm{~nm}$, with phosphate buffer as a reference. The ABTS $^{+\bullet}$ scavenging activity was expressed as $\mathrm{mg}$ Trolox equivalents/g DM.

Quencher-ABTS $^{+\bullet}$ assay $\left(\mathrm{ABTS}^{+\bullet}\right.$-QA) was performed according to Gökmen et al. [29]. Briefly, $10 \mathrm{mg}$ of lyophilized material was mixed with $30 \mathrm{~mL}$ of $\mathrm{ABTS}^{+\bullet}$ solution (initial absorbance $0.7 \pm 0.02$ at $734 \mathrm{~nm}$ ), and shaken at room temperature in the dark. After $7 \mathrm{~min}$, the absorbance of filtered samples was measured at $734 \mathrm{~nm}$, with phosphate buffer as a reference. The ABTS ${ }^{+\bullet}$ scavenging activity was expressed as mg Trolox equivalents/g DM.

\subsection{Phenolic Profile}

The profile of phenolic compounds extractable in buffer was estimated according to Lin et al. [30] with some modifications concerning the initial composition of mobile phase and time of analysis.

\subsubsection{LC-DAD Condition}

The LC-DAD instrument consisted of an HPLC (Biorad Lab., Herkules, CA. USA) coupled with a diode array detector (DAD) and a column LUNA C18 $(5 \mu \mathrm{m}, 250 \times 4.6 \mathrm{~mm})$ was used at a flow 
rate of $1.0 \mathrm{~mL} / \mathrm{min}$. The column oven temperature was set at $25^{\circ} \mathrm{C}$. The mobile phase consisted of a combination of $\mathrm{A}(0.1 \%$ formic acid in water) and B (0.1\% formic acid in acetonitrile). The gradient was varied linearly from 5\% to $10 \% \mathrm{~B}(v / v)$ in $10 \mathrm{~min}$, from $10 \%$ to $26 \% \mathrm{~B}(\mathrm{v} / \mathrm{v})$ in $40 \mathrm{~min}$, to $65 \% \mathrm{~B}$ in $80 \mathrm{~min}$ and finally to $100 \% \mathrm{~B}$ in $81 \mathrm{~min}$ and held at $100 \% \mathrm{~B}$ to $85 \mathrm{~min}$. Finally, the column was equilibrated for $10 \mathrm{~min}$. The DAD was set at 230, 257, 274, 310 and $350 \mathrm{~nm}$ for real-time read-out, and UV/VIS spectra, from 190 to $650 \mathrm{~nm}$, were continuously collected.

\subsubsection{LC-DAD Condition}

One gram of lyophilized material was extracted with $10 \mathrm{~mL}$ of phosphate buffer $(0.02 \mathrm{~mol} / \mathrm{L}$, pH 7.4) for $3 \mathrm{~h}$, centrifuged (10,000 rpm, $15 \mathrm{~min})$ and then filtered through a $0.45 \mu \mathrm{m} 13 \mathrm{~mm}$ Nylon syringe filter (FilterBio ${ }^{\circledR}$ NY Syringe Filter, Labex Ltd., Nantong City, Jiangsu P.R, China). A $50 \mu L$ of the extract or standard $(1 \mathrm{mg} / 100 \mathrm{~mL}$ of buffer) was injected into the column for analysis.

\subsection{In Vitro Digestion}

Lyophilized material was digested using the method with pepsin and pancreatin, as described in Stodolak et al. [31]. Briefly, $0.5 \mathrm{~g}$ of material with the addition of $1.7 \mathrm{mg}$ of pepsin (Sigma, Steinheim, Germany, $4750 \mathrm{U} / \mathrm{mg}$ ) dissolved in $0.1 \mathrm{~mol} / \mathrm{L} \mathrm{HCl}$ was incubated at $37^{\circ} \mathrm{C}, \mathrm{pH} 2.0$ for $2 \mathrm{~h}$. Then, $2.5 \mathrm{mg}$ of pancreatin (Sigma, from porcine pancreas, $8 \times$ USP specifications) dissolved in $0.1 \mathrm{~mol} / \mathrm{L} \mathrm{NaHCO}_{3}$ was added and the sample was incubated at $30^{\circ} \mathrm{C}, \mathrm{pH} 7.0$ for $4 \mathrm{~h}$ in dialysis tubes (Sigma Aldrich, cellulose membrane $25 \mathrm{~mm} \times 16 \mathrm{~mm}$, retaining most proteins with molecular weight $\geq 12,000$ ) immersed in $50 \mathrm{~mL}$ of phosphate buffer $(0.2 \mathrm{~mol} / \mathrm{L}, \mathrm{pH} 7.0)$. In dialysates (phosphate buffer with the compounds that passed the membrane), the level of FCRS (mg gallic acid/g DM) and activity against ABTS ${ }^{+\bullet}$ and $\bullet \mathrm{OH}$ (mg Trolox equivalents/g DM) were estimated.

\subsection{Statistical Analysis}

For the in vitro digestion test, four samples were prepared, each analysed in two replications. For the other analyses four replications were made. The results were statistically evaluated using the two-way analysis of variance (with the exception of glucosamine and phenolic compounds profile-one-way ANOVA), where factor 1 was a treatment kind and factor 2 was a substrate kind. To determine statistically significant differences, the Tukey post-hoc test was used $(p \leq 0.05)$. To estimate correlation between parameters, regression analyses were done at $p \leq 0.05$. Data were processed using Statistica version 12.0 software (StatSoft, Inc., Tulsa, OK, USA).

\section{Conclusions}

In this paper, we show that an addition of $20 \%$ flaxseed oil-cake and the application of bacterialfungal co-fermentation, can be considered as an effective tool to improve the antioxidant potential of grass pea tempe. The co-fermented tempe was enriched in phenolic acids (gallic acid, protocatechuic acid) and had higher antioxidant activity than the fungal fermentation products. Moreover, after in vitro digestion, more antioxidant compounds were released from tempe obtained with the use of mixed inoculum than from the mould-fermented products.

Author Contributions: Conceptualization, B.S.; methodology, B.S., A.S.-J. and M.M; investigation, B.S., A.S.-J. and M.M.; resources, B.S. and A.S.-J; formal analysis, B.S.; writing-original draft preparation, B.S.; writing-review and editing, A.S.-J. and A.W.; visualization, B.S. and M.M.; supervision, B.S. All authors have read and agreed to the published version of the manuscript.

Funding: This research was funded by the MINISTRY OF SCIENCE AND HIGHER EDUCTATION OF PLAND, grant number DS-3702/KBZ̈/2018.

Conflicts of Interest: The authors declare no conflict of interest. 


\section{References}

1. Nout, M.R.; Kiers, J. Tempe fermentation, innovation and functionality: Update into the third millenium. J. Appl. Microbiol. 2005, 98, 789-805. [CrossRef]

2. Rybiński, W.; Karamać, M.; Sulewska, K.; Börner, A.; Amarowicz, R. Antioxidant Potential of Grass Pea Seeds from European Countries. Foods 2018, 7, 142. [CrossRef]

3. Starzyńska-Janiszewska, A.; Stodolak, B.; Jamróz, M. Antioxidant properties of extracts from fermented and cooked seeds of Polish cultivars of Lathyrus sativus. Food Chem. 2008, 109, 285-292. [CrossRef]

4. Meral, R.; Sait Dogan, I. Quality and antioxidant activity of bread. Italy J. Food Sci. 2013, 25, 51-57.

5. Stodolak, B.; Starzyńska-Janiszewska, A.; Wikiera, A. Effect of flaxseed oil cake addition on antioxidant potential of grass pea tempeh. Zywnosc.Nauka.Technologia.Jakosc/Food.Science.Technology.Quality 2015, 22, 96-105. [CrossRef]

6. Kasote, D.M. Flaxseed phenolics as natural antioxidants. Int. Food Res. J. 2013, 20, $27-34$.

7. Starzyńska-Janiszewska, A.; Stodolak, B.; Mickowska, B. Effect of controlled lactic acid fermentation on selected bioactive and nutritional parameters of tempeh obtained from unhulled common bean (Phaseolus vulgaris) seeds. J. Sci. Food Agric. 2013, 94, 359-366. [CrossRef]

8. Rodríguez, H.; Curiel, J.A.; Landete, J.M.; Rivas, B.D.L.; De Felipe, F.L.; Gómez-Cordovés, C.; Mancheño, J.M.; Muñoz, R. Food phenolics and lactic acid bacteria. Int. J. Food Microbiol. 2009, 132, 79-90. [CrossRef]

9. McCue, P.; Horii, A.; Shetty, K. Solid-state bioconversion of phenolic antioxidants from defatted soybean powders by rhizopus oligosporus: Role of carbohydrate-cleaving enzymes. J. Food Biochem. 2003, 27, 501-514. [CrossRef]

10. Bhanja, T.; Kumari, A.; Banerjee, R. Enrichment of phenolics and free radical scavenging property of wheat koji prepared with two filamentous fungi. Bioresour. Technol. 2009, 100, 2861-2866. [CrossRef]

11. Gan, R.-Y.; Shah, N.P.; Wang, M.-F.; Lui, W.-Y.; Corke, H. Fermentation alters antioxidant capacity and polyphenol distribution in selected edible legumes. Int. J. Food Sci. Technol. 2016, 51, 875-884. [CrossRef]

12. Rui, X.; Wang, M.; Zhang, Y.; Chen, X.; Li, L.; Liu, Y.; Dong, M.S. Optimization of soy solid-state fermentation with selected lactic acid bacteria and the effect on the anti-nutritional components. J. Food Process. Preserv. 2017, 41, 41. [CrossRef]

13. Wang, Y.-K.; Zhang, X.; Chen, G.-L.; Yu, J.; Yang, L.-Q.; Gao, Y.-Q. Antioxidant property and their free, soluble conjugate and insoluble-bound phenolic contents in selected beans. J. Funct. Foods 2016, 24, 359-372. [CrossRef]

14. Reshma, M.; Namitha, L.; Sundaresan, A.; Kiran, C.R. Total Phenol Content, Antioxidant Activities and $\alpha$-Glucosidase Inhibition of Sesame Cake Extracts. J. Food Biochem. 2012, 37, 723-731. [CrossRef]

15. Terpinc, P.; Ceh, B.; Ulrih, N.P.; Abramovič, H. Studies of the correlation between antioxidant properties and the total phenolic content of different oil cake extracts. Ind. Crops Prod. 2012, 39, 210-217. [CrossRef]

16. Fratianni, F.; Cardinalea, F.; Cozzolino, A.; Granese, T.; Albanese, D.; Di Matteo, M.; Zaccardelli, M.; Coppola, R.; Nazzaro, F. Polyphenol composition and antioxidant activity of different grass pea (Lathyrus sativus), lentils (Lens culinaris), and chickpea (Cicer arietinum) ecotypes of the Campania region (Southern Italy). J. Funct. Foods 2014, 7, 551-557. [CrossRef]

17. Singh, B.; Singh, J.P.; Kaur, A.; Singh, N. Phenolic composition and antioxidant potential of grain legume seeds: A review. Food Res. Int. 2017, 101, 1-16. [CrossRef]

18. Struijs, K.; Vincken, J.-P.; Doeswijk, T.G.; Voragen, A.; Gruppen, H. The chain length of lignan macromolecule from flaxseed hulls is determined by the incorporation of coumaric acid glucosides and ferulic acid glucosides. Phytochemistry 2009, 70, 262-269. [CrossRef]

19. Aguilar, C.N.; Rodríguez, R.; Gutiérrez-Sánchez, G.; Augur, C.; Favela-Torres, E.; Prado-Barragan, L.A.; Ramírez-Coronel, A.; Contreras-Esquivel, J.C. Microbial tannases: Advances and perspectives. Appl. Microbiol. Biotechnol. 2007, 76, 47-59. [CrossRef]

20. Wright, J.D. Fungal degradation of benzoic acid and related compounds. World J. Microbiol. Biotechnol. 1993, 9, 9-16. [CrossRef]

21. Sachan, S.G.; Ghosh, S.; Sen, S.K.; Mitra, A. Co-production of caffeic acid and p-hydroxybenzoic acid from p-coumaric acid by Streptomyces caeruleus MTCC 6638. Appl. Microbiol. Biotechnol. 2005, 71, 720-727. [CrossRef] 
22. Heleno, S.A.; Martins, A.; Queiroz, M.-J.R.; Ferreira, I.C. Bioactivity of phenolic acids: Metabolites versus parent compounds: A review. Food Chem. 2015, 173, 501-513. [CrossRef]

23. Masella, R.; Santangelo, C.; D'Archivio, M.; Volti, G.L.; Giovannini, C.; Galvano, F. Protocatechuic acid and human disease prevention: Biological activities and molecular mechanisms. Curr. Med. Chem. 2012, 19, 2901-2917. [CrossRef]

24. Sánchez-Maldonado, A.; Schieber, A.; Gänzle, M. Structure-function relationships of the antibacterial activity of phenolic acids and their metabolism by lactic acid bacteria. J. Appl. Microbiol. 2011, 111, 1176-1184. [CrossRef]

25. Calixto, F.D.S.; Serrano, J.; Goñi, I. Intake and bioaccessibility of total polyphenols in a whole diet. Food Chem. 2007, 101, 492-501. [CrossRef]

26. Swain, T.; Hillis, W.E. The phenolic constituents ofPrunus domestica. I.-The quantitative analysis of phenolic constituents. J. Sci. Food Agric. 1959, 10, 63-68. [CrossRef]

27. Marambe, P.W.M.L.H.K.; Shand, P.J.; Wanasundara, J.P. An In-vitro Investigation of Selected Biological Activities of Hydrolysed Flaxseed (Linum usitatissimum L.) Proteins. J. Am. Oil Chem. Soc. 2008, 85, 1155-1164. [CrossRef]

28. Caño, A.; Acosta, M.; Arnao, M.B. Hydrophilic and lipophilic antioxidant activity changes during on-vine ripening of tomatoes (Lycopersicon esculentum Mill.). Postharvest Biol. Technol. 2003, 28, 59-65. [CrossRef]

29. Gökmen, V.; Serpen, A.; Fogliano, V. Direct measurement of the total antioxidant capacity of foods: The ‘QUENCHER' approach. Trends Food Sci. Technol. 2009, 20, 278-288. [CrossRef]

30. Lin, L.-Z.; Harnly, J.M.; Pastor-Corrales, M.S.; Luthria, D.L. The polyphenolic profiles of common bean (Phaseolus vulgaris L.). Food Chem. 2008, 107, 399-410. [CrossRef]

31. Stodolak, B.; Starzyńska-Janiszewska, A.; Pustkowiak, H.; Mickowska, B. Effect of sunflower seeds addition on the nutritional value of grass pea tempeh. Pol. J. Food Nutr. Sci. 2009, 59, 145-150.

Sample Availability: Not available.

Publisher's Note: MDPI stays neutral with regard to jurisdictional claims in published maps and institutional affiliations.

(C) 2020 by the authors. Licensee MDPI, Basel, Switzerland. This article is an open access article distributed under the terms and conditions of the Creative Commons Attribution (CC BY) license (http://creativecommons.org/licenses/by/4.0/). 